\title{
The first high resolution diatom record from Lake Balaton, Hungary in Central Europe
}

\author{
Krisztina Buczkó ${ }^{1,2,}$, Éva Ács ${ }^{1}$, Katalin Báldi ${ }^{3}$, Virág Pozderka ${ }^{4}$, Mihály Braun ${ }^{5}$, Keve \\ Tihamér Kiss ${ }^{1}$ and János Korponai6,7
}

${ }^{1}$ MTA Centre for Ecological Research, Danube Research Institute, 1113 Budapest, Karolina St 29, Hungary.

2 Hungarian Natural History Museum, Department of Botany, 1088 Budapest, Baross St 13, Hungary.

3 Eötvös Loránd University, Department of Physical \& Applied Geology, 1117 Budapest, Pázmány Péter St 1/c, Budapest, Hungary.

${ }^{4}$ Eötvös Loránd University, Doctoral School of Environmental Sciences, 1117 Budapest, Pázmány Péter St 1/c, Budapest, Hungary.

5 Isotope Climatology and Environmental Research Centre (ICER), Institute for Nuclear Research, Hungarian Academy of Sciences, 4026 Debrecen, Bem Square 18/C, Hungary.

${ }^{6}$ Department of Environmental Sciences, Sapientia Hungarian University of Transylvania, 400193 Cluj-Napoca, Calea Turzii str. 4., Romania.

${ }^{7}$ MTA - PE Limnoecology Research Group, 8200 Veszprém, Wartha Vince St 1. Hungary.

* Corresponding author: buczko.krisztina@okologia.mta.hu

Received: 13/04/18

Accepted: 19/11/18

\begin{abstract}
The first high resolution diatom record from Lake Balaton, Hungary in Central Europe

A high-resolution diatom record of the last 7500 years of Lake Balaton, a large, shallow calcareous lake in Central Europe is presented here. Diatom analyses were carried out on a $112 \mathrm{~cm}$ long core obtained from the Siófok Basin (eastern part of the lake) combined with loss-on-ignition, geochemical measurements and grain-size analysis. Altogether 140 diatom taxa were distinguished in this study; Amphora pediculus, Cocconeis neothumensis, Fragilaria brevistriata and Karayevia clevei were frequent and ubiquitous members of diatom assemblages. Fragilaroid taxa were dominant through the core in the shallow Lake Balaton, but episodes of higher ratios of planktic forms (Lindavia balatonis, Aulacoseira granulata and Pantocsekiella ocellata) before ca. $2000 \mathrm{cal} \mathrm{yr} \mathrm{BP}$, indicated high water level in the lake, and stronger fluctuation than exists today. The diatom-based reconstruction of lake level was in accordance with the geochemical and zoological records, proving the usability of siliceous remains in paleolimnological reconstructions in Lake Balaton, in spite of the unfavourable preservation conditions.
\end{abstract}

Key words: diatoms, geochemistry, Lake Balaton, lake level changes, shallow lake sediments

\section{RESUMEN}

\section{El primer registro de diatomeas de alta resolución del lago Balaton, Hungría, en Europa Central}

Aqui se presenta un registro de diatomeas de alta resolución del lago Balaton de los últimos 7500 años, un gran lago calcáreo poco profundo en Europa Central. Los análisis de diatomeas se llevaron a cabo en un testigo sedimentario de $112 \mathrm{~cm}$ de longitud obtenido en la cuenca Siófok (parte oriental del lago), combinado con pérdidas por ignición (LOI), mediciones geoquímicas y análisis de tamaño de grano. En este estudio se distinguieron 140 taxones de diatomeas; Amphora pediculus, Cocconeis neothumensis, Fragilaria brevistriata $y$ Karayevia clevei fueron miembros frecuentes y ubicuos de los conjuntos de diatomeas. Los taxones de Fragilaroides eran dominantes a través del testigo en el somero lago Balaton, pero los episodios de mayor proporción de formas planctónicas (Lindavia balatonis, Aulacoseira granulata y Pantocsekiella ocellata) antes de ca. 2000 calyr BP, indicaron un nivel de agua alto en el lago y una fluctuación más fuerte que la que existe hoy en día. La reconstrucción del nivel del lago basada en diatomeas estuvo de acuerdo con los registros geoquímicos y zoológicos, 
demostrando la utilidad de los restos siliceos en reconstrucciones paleolimnológicas en el lago Balaton, a pesar de las condiciones de preservación desfavorables.

Palabras clave: diatomeas, geoquímica, lago Balaton, cambios en el nivel del lago, sedimentos someros del lago

\section{INTRODUCTION}

Lakes are complex ecosystems, playing vital roles in regulating the global hydrological and biogeochemical cycles and acting as important parts of the global biosphere (Romero-Viana et al., 2009; Williamson et al., 2009). Paleolimnology - a rapidly developing field of science gathers information about the ontogeny of different kinds of waterbodies, mires, wetlands, ponds and lakes. Among these, shallow lakes are extremely sensitive to any stressors, even as they carry exceptionally high biological conservation values (Kearns et al., 1996, Heinsalu et al., 2007b). Shallow lakes and wetlands are important subjects of hydrological reconstruction, as they are more vulnerable than deep lakes to water level fluctuation. Even a small scale variation can cause considerable changes due to their shallowness. It is especially true for such a large and shallow lake as Lake Balaton, where the wind, combined with shallowness makes the lake prone to resedimentation, affecting benthic life (Korponai et al., 2010).

Diatoms are unicellular algae; they are sensitive indicators of environmental changes. They have been successfully used to monitor disturbances, like eutrophication, changes to the physical and chemical properties of water, as well as fluctuations of water level (Stoermer \& Smol 1999). However, though there is a wide consensus about the usefulness of diatoms in quantitative paleolimnological reconstruction (Stoermer \& Smol 1999; Romero-Viana et al., 2009; Heinsalu et al., 2007a, 2007b), in Lake Balaton, no high-resolution diatom record has been published so far; therefore, the study presented here is entirely new.

\section{Paleolimnological research on Lake Balaton}

In spite of the intensive and continuous long-term neolimnological studies of Lake Balaton (Hat- vani et al., 2011, Istvánovics \& Honti, 2018), the paleolimnological exploration of the lake is sparse and uneven, and is sometimes even questioned (WEB1 2018). There has been no comprehensive modern survey conducted on the entire lake, and only limited efforts were made for using multi-proxy approaches for paleoecological reconstruction concerning the history of the lake. In particular, the possibly uneven and dissimilar development of the different basins of Lake Balaton has been neglected.

Nevertheless, from the end of the nineteenth century, the lake and its surroundings have been intensively studied (Lóczy, 1916). It must be mentioned about this period that the first diatom record by J. Pantocsek (1913) presented a very low-resolution list with presence/absence data of a 4 meter long core from Siófok Basin.

In 1981, the Geological Institute of Hungary (MÁFI) initiated a comprehensive survey of the limnogeology of Lake Balaton. Altogether 33 boreholes were drilled into the Quaternary layers down to 10-12 m. The thickness of the Holocene mud was 5 meters on average, but it was widely varying from place to place, e.g. 10 meters in the western basin and less than 2 meters in the eastern end of the lake (Cserny \& Nagy-Bodor 2000, Cserny 2002, Tullner \& Cserny, 2003). These studies revealed that Lake Balaton is 15000 17000 years old, and its development started with the formation of several shallow water lakes. Buczkó et al. (2005) summarised the diatom data gathered by Márta Hajós working on 18 of these 33 cores. More than 350 taxa were listed in this compilation, but evaluation of data has never been completed. Shortcomings of the Márta Hajós dataset preclude it from being used in this study. No standard counting methods were followed (e.g. Battarbee, 1986), resulting in varying sample sizes, where the number of counted valves could range from less than ten to 1300 valves (Tó-29). Sometimes, even the counted valves of different slides were merged into one 
single entry in the database. Consequently, there is no simple statistical method that can be applied for the Márta Hajós dataset. Additionally, in these 33 cores, the organic content of samples was not measured, leaving us without this standard geochemical proxy.

More recently Korponai et al. (2010) made the first attempt to use multi-proxy methods in the ancient Lake Balaton where extended wetlands were recently reconstructed (Hatvani et al., 2011). The site for coring was chosen in a formerly water covered area on the south-western part of the lake. Three different stages were established concerning water level on the basis of geochemical data, subfossil Cladocera and diatom remains in the sediments of the Zalavár Pond, a part of the Kis-Balaton wetland (Buczkó et al., 2009; Korponai et al., 2010). It should be emphasized that the coring site of Korponai et al. (2010) is beyond the present day open-water part of Lake Balaton, so the result of this multi-proxy study has its limitations concerning the history of the lake compared to the present coring site posi- tioned centrally in a sedimentary basin which provides a sedimentary record embracing a longer time period.

Within the frame of the EuLakes project (WEB1 2018), there was an attempt to use high-resolution trophic reconstruction in the south-western basin of Lake Balaton. In conclusion, the applicability of diatom analyses was questioned for such a shallow, wind disturbed, calcareous lake as Lake Balaton (WEB1 2018).

The present study is, first of all, intended to test the applicability of diatoms as a paleolimnological proxy in the eastern basin of Lake Balaton. The goals of this work are twofold: first, to publish the first high-resolution diatom record from Lake Balaton with special attention to the preservation of small celled valves; secondly, to perform lake level reconstruction, using geochemistry, and subfossil diatom remains in the sediment. To achieve these goals, the Siófok Basin at the eastern end of Lake Balaton, characterized by high human pressure, but low direct input from the watershed, was chosen (Fig. 1.).

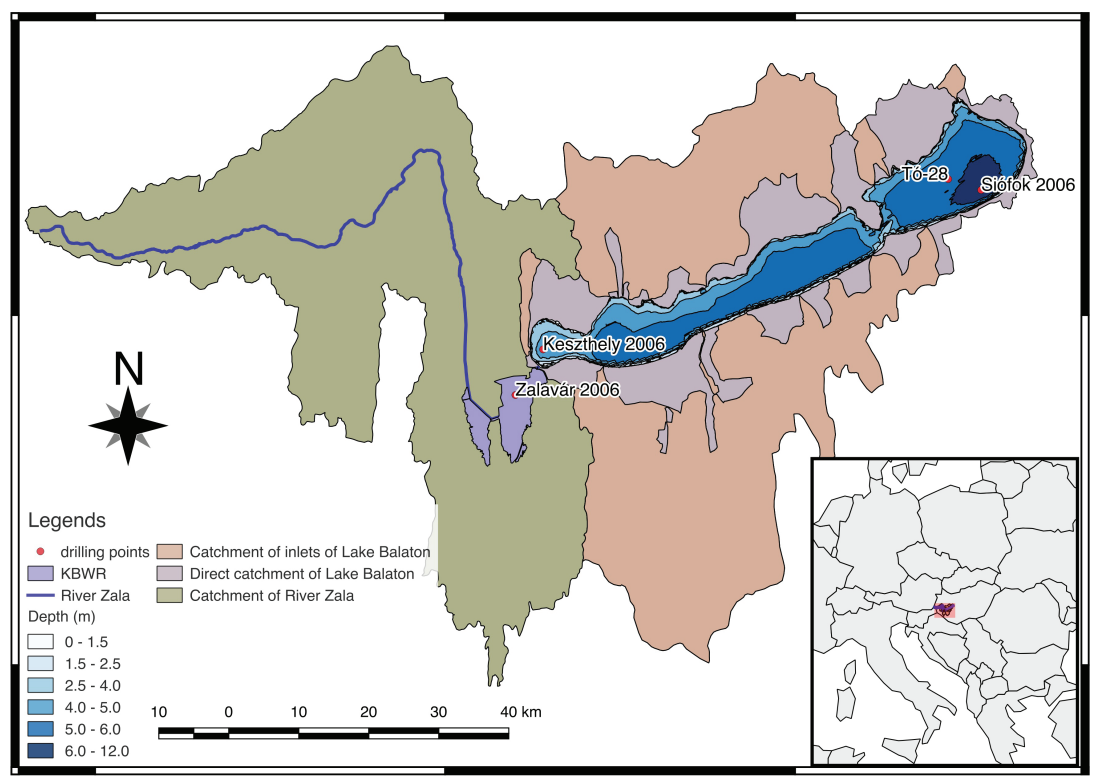

Figure 1. Lake Balaton and its catchment area. Note the four basins (Keszthely, Szigliget; Szemes, Siófok) and the difference between theirs catchment area size. Three cores were drilled in 2006 (Buczkó et al., 2009, Korponai et al., 2010). Tó-28 drilled within the MÁFI actual geological survey (Cserny, 2002, Rokob et al., 2008). El Lago Balaton y su área de influencia. Tenga en cuenta las cuatro cuencas (Keszthely, Szigliget, Szemes, Siófok) y la diferencia entre el tamaño de su área de influencia. Se perforaron tres testigos sedimentarios en 2006 (Buczkó et al., 2009, Korponai et al., 2010). Tó-28 perforado dentro de una verdadera investigación geológica MÁFI (Cserny. 2002, Rokob et al., 2008). 


\section{MATERIAL AND METHODS}

\section{Study site}

Lake Balaton, the largest shallow lake in Central Europe, is one of the best studied lakes in the world (Entz \& Sebestyén 1946, Istvánovics et al., 2007, Istvánovics \& Honti 2018). Its catchment area is $5175 \mathrm{~km}^{2}$, with a major inflow, the Zala River in the west, with an average discharge of about $5-10 \mathrm{~m}^{3} / \mathrm{seg}$. The only outflow is the artificial Sió canal constructed in the 1860 s connecting the lake to the Danube River (Fig. 1). The Zala River enters Lake Balaton through the Kis-Balaton Wetland, a large area acting as a natural filter for suspended material and nutrients that would otherwise be deposited in the lake (Fig. 1. Hatvani et al., 2011). The lacustrine sediments are rich in carbonate (calcareous mud) increasing from south-west (Keszthely) to north-east (Siófok) (Cserny \& Nagy-Bodor, 2000; Tullner \& Cserny, 2003).

\section{Field and laboratory methods}

A sediment core (SIOFOK2006) of $112 \mathrm{~cm}$ length was obtained from the deepest, central part of the Siófok Basin in Lake Balaton (Fig. 1.) with a 5 $\mathrm{cm}$ diameter Livingston piston sampler in May 2006. Subsamples were taken at every second $\mathrm{cm}$ for siliceous algae, grain size and geochemical analyses. The procedure for grain size determination started with disaggregation by shaking wet samples for 24 hours before fractionating them in a settling column. For loss-on-ignition analysis, samples were weighed and heated at $5500^{\circ} \mathrm{C}$ for 4 hours (Heiri et al., 2001) and at $950{ }^{\circ} \mathrm{C}$ for 2 hours. Trace element content was determined by
ICP-OES - Thermo Iris Intrepid II XSP (Korponai et al., 2010). For radiocarbon calibration of the core, macrophyte and charred plant remains were selected and (Table 1) analysed at the Laboratory of Environmental Studies, Institute of Nuclear Research, Hungarian Academy of Sciences in Debrecen. Dates were calibrated using the software CALIB REV5.0.0 (Stuiver et al., 2005).

In order to analyse siliceous algae, sediment samples were prepared using standard digestion procedures (10\% hydrochloric acid, and $30 \%$ $\mathrm{H}_{2} \mathrm{O}_{2}$ hot hydrogen-peroxide) (Battarbee, 1986), and at least 400 valves were counted in each sediment layer. For light microscope analysis, a LEICA DM LB2 was used (100 X HCX PLAN APO). Diatom identification followed the nomenclature of Hofmann et al. (2011) and Wetzel et al. (2015) for small celled naviculoids. Nomenclature was checked and updated according to AlgaeBase (Guiry \& Guiry, 2016), accessed 2-25 April 2016, except genus Pantocsekiella where the concept of Ács et al. (2016) was followed. Stratigraphic zone boundaries were defined using CONISS on square-root transformed data without downweighting of rare taxa with the Psimpoll 4.27 program (Bennett, 2005). The significant number of diatom assemblage zones (DAZ) was assessed by a broken-stick model implemented in "Rioja" package (Juggins, 2012).

\section{RESULTS}

\section{Physical properties of the core}

Lithology, age, organic material content expressed in loss on ignition (LOI) at $550{ }^{\circ} \mathrm{C}$ and at $950^{\circ} \mathrm{C}, \mathrm{Ca}$ and $\mathrm{Mg}$ content, $\mathrm{Fe}$ and $\mathrm{Mn}$ content and their ratio according to the grain size distribu-

Table 1. Results of the ${ }^{14} \mathrm{C}$ dating measurements, SIOFOK2006 core; Lake Balaton. Resultados de las dataciones con ${ }^{14} \mathrm{C}$, testigo SIOFOK2006; Lago Balaton.

\begin{tabular}{|c|c|c|c|c|c|}
\hline Lab-code & $\begin{array}{l}\text { Depth below core } \\
\text { top }(\mathrm{cm})\end{array}$ & $\begin{array}{c}\mathrm{D} 13 \mathrm{C}(\mathrm{PDB}) \\
\pm 0.2[\% \mathrm{o}]\end{array}$ & ${ }^{14} \mathrm{C}$ year BP & $\begin{array}{c}\text { Cal. year (2s) } \\
\text { Cal yr BP }\end{array}$ & $\begin{array}{l}\text { Mid-point of } 2 \text { sigma } \\
\text { calibrated age range }\end{array}$ \\
\hline deb-13938 & Siófok 59-64 cm & -0.53 & $3920 \pm 50$ & $4468-4516$ & 4492 \\
\hline deb-13947 & Siófok $104-109 \mathrm{~cm}$ & +1.05 & $6330 \pm 60$ & $7158-7421$ & 7394 \\
\hline
\end{tabular}


Lake Balaton Siófok basin SIOFOK2006

Analysed by M. Braun 2006-2007

Grain size distribution

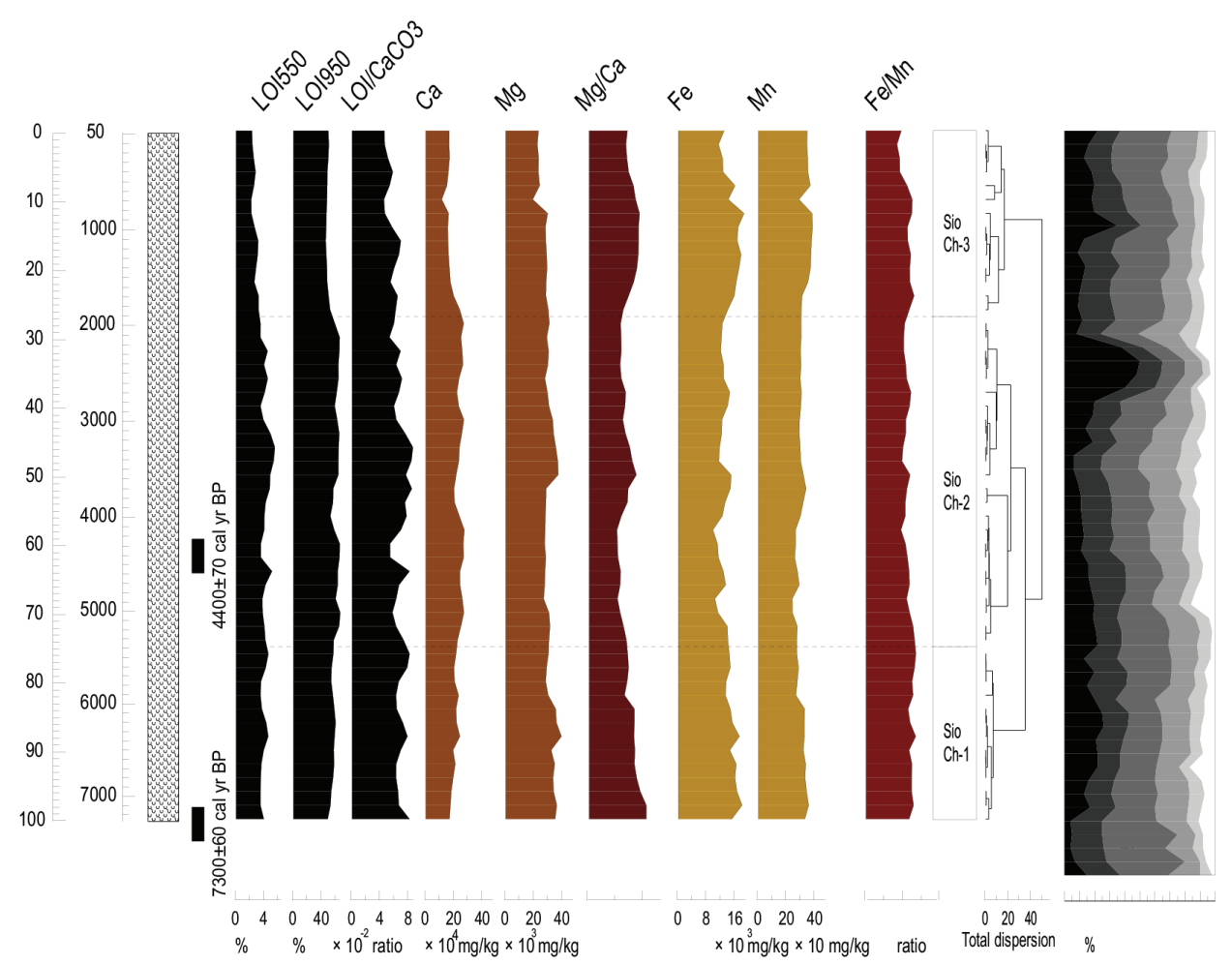

Figure 2. Physical properties of the core SIOFOK2006, Siófok Basin, Lake Balaton. Lithology, organic material content, main cations ( $\mathrm{Ca}, \mathrm{Mg}, \mathrm{Fe}, \mathrm{Mn}) ; \mathrm{Mg} / \mathrm{Ca}$ and $\mathrm{Fe} / \mathrm{Mn}$ ratios are also plotted. Sio-Ch: local geochemical assemblage zones. Grain-size distribution, Sio-Gr: local grain size assemblage zones. Propiedades fisicas del testigo SIOFOK2006, Cuenca Siófok, Lago Balaton. Litología, contenido en materia orgánica, principales cationes (Ca, Mg, Fe, Mn); También se han representado las relaciones $\mathrm{Mg} / \mathrm{Ca}$ y Fe/Mn. Sio-Ch: Zonas de agrupación geoquímica. Distribución granulométrica, Sio-Gr: Zonas granulométricas.

tion are presented in Figure 2. Although the core SIOFOK2006 turned out to be quite uniform, homogeneous and unvaried in terms of lithology, and geochemistry, e.g. organic material content. Still, three zones could be distinguished.

Organic material content estimated by $\mathrm{LOI}_{550}$ is low, varying in a very narrow range (2-5\%), and shows some decrease at the top of the core. The $\mathrm{LOI}_{950}$ is high (40-65\%) and indicates three intervals. It is lowest at the top $30 \mathrm{~cm}$. Higher values characterize the region between 30 and 75 $\mathrm{cm}$, whereas below $75 \mathrm{~cm}$ has lower values. The topmost sample does not show high LOI values ( $\mathrm{LOI}_{550} 2 \%$ and $\mathrm{LOI}_{950} 46 \%$ ) indicating continuously disturbed, mixed sediments, preventing rich benthic vegetation on the bottom of the lake.
Five zones (Sio-Gr1-Sio-Gr5) were distinguished using the grain size distribution (Fig. 2). Generally, the core is silty, except for a sand fraction peaking between 28 and $38 \mathrm{~cm}$, with grains of calcareous aggregates, most likely formed autogenetically as part of diagenetic processes.

The two successful measurements of radiocarbon dates are presented in Table 1. A linear sedimentation rate model was applied, establishing the linear relationship between age and depth. The high carbonate and low organic content complicated the radiocarbon dating of the core, making the applied time frame less than ideal concerning reliability. The studied $112 \mathrm{~cm}$ long core spans ca. 7500 years. 
Table 2. List of diatom taxa in SIOFOK 2006 core was found $>5 \%$ in relative abundance in samples (\%). The first column gives the taxon relative abundance in the whole core, while the second column show the number of occurrences in the 53 studied samples. La lista de taxones de diatomeas en el testigo SIOFOK2006 fue > 5\% en abundancia relativa en las muestras (\%). La primera columna da la abundancia relativa del taxón en todo el testigo, mientras que en la segunda columna muestra el número de ocurrencias en las 53 muestras estudiadas.

\begin{tabular}{|c|c|c|}
\hline List of taxa in Siofók Basin of lake Balaton (V. Pozderka 2015-2016) & $\begin{array}{c}\text { Relative } \\
\text { abundance }\end{array}$ & Frequency \\
\hline Amphora copulata (Kützing) Schoeman \& R.E.M.Archibald & 0.83 & 42 \\
\hline Amphora pediculus (Kützing) Grunow ex A.Schmidt & 7.65 & 54 \\
\hline Aneumastus minor Lange-Bertalot & 0.2 & 23 \\
\hline Aneumastus tuscula (Ehrenberg) D.G.Mann \& A.J.Stickle in Round, Crawford \& D.G.Mann & 0.11 & 15 \\
\hline Aulacoseira granulata (Ehrenberg) Simonsen & 6.95 & 54 \\
\hline Belonastrum berolinensis (Lemmermann) Round \& Maidana & 2.73 & 51 \\
\hline Biremis zachariasii (Reichelt) Edlund, N.A.Andresen \& Soninkhisig & 0.28 & 23 \\
\hline Caloneis schumanniana (Grunow) Cleve & 0.15 & 5 \\
\hline Campylodiscus hibernicus Ehrenberg & 0.12 & 14 \\
\hline Cavinula jaernefeltii (Hustedt) D.G.Mann \& A.J.Stickle in Round. Crawford \& D.G.Mann & 0.1 & 6 \\
\hline Cavinula scutelloides (W.Smith) Lange-Bertalot in Lange-Bertalot \& Metzeltin & 0.46 & 39 \\
\hline Cocconeis neodiminuta Krammer & 2.2 & 46 \\
\hline Cocconeis neothumensis Krammer & 2.65 & 54 \\
\hline Cymbopleura inaequalis (Ehrenberg) Krammer & 0.13 & 5 \\
\hline Diploneis elliptica (Kützing) Cleve & 0.12 & 9 \\
\hline Diploneis oblongella (Nägeli ex Kützing) Cleve-Euler & 0.44 & 16 \\
\hline Diploneis oculata (Brébisson) Cleve & 0.29 & 11 \\
\hline Diploneis pseudovalis Hustedt & 0.96 & 37 \\
\hline Fallacia subhamulata (Grunow) D.G.Mann in Round. R.M.Crawford \& D.G.Mann & 0.22 & 17 \\
\hline Fragilaria brevistriata Grunow in van Heurck & 21.06 & 54 \\
\hline Fragilaria construens (Ehrenberg) Grunow & 3.11 & 37 \\
\hline Gyrosigma acuminatum (Kützing) Rabenhorst & 1.27 & 45 \\
\hline Hippodonta costulata (Grunow) Lange-Bertalot. Metzeltin \& Witkowski & 1.88 & 41 \\
\hline Karayevia clevei (Grunow) Round \& Bukhtiyarova & 3.24 & 53 \\
\hline Lindavia balatonis (Pantocsek) T.Nakov et al., & 0.96 & 25 \\
\hline Navicula cryptotenella Lange-Bertalot in Krammer \& Lange-Bertalot & 0.15 & 11 \\
\hline Navicula menisculus Schumann & 0.14 & 13 \\
\hline Navicula seminuloides Hustedt & 9.34 & 52 \\
\hline Neidium binode (Ehrenberg) Hustedt & 0.24 & 23 \\
\hline Neidium dubium (Ehenberg) Cleve & 0.15 & 21 \\
\hline Neidium iridis (Ehrenberg) Cleve & 0.1 & 5 \\
\hline
\end{tabular}


Table 2. (cont.)

$\begin{array}{lrr}\text { Nitzschia recta } \text { Hantzsch ex Rabenhorst } & 0.1 & 10 \\ \text { Pantocsekiella ocellata (Pantocsek) Kiss \& Ács } & 1.34 & 43 \\ \text { Parlibellus crucicula (W.Smith) Witkowski, Lange-Bertalot \& Metzeltin } & 0.16 & 21 \\ \text { Pinnularia balatonis (Pantocsek) Mills } & 0.13 & 15 \\ \text { Pinnularia viridis (Nitzsch) Ehrenberg } & 0.17 & 12 \\ \text { Placoneis pseudanglica } \text { E.J.Cox } & 0.23 & 27 \\ \text { Pseudostaurosira parasitica (W.Smith) Morales } & 0.86 & 39 \\ \text { Sellaphora nigri (De Notaris) C.E.Wetzel \& L.Ector in Wetzel et al., } & 1.36 & 30 \\ \text { Sellaphora rotunda (Hustedt) C.E.Wetzel. L.Ector. B.Van de Vijver. P.Compère \& } & & \\ \text { D.G.Mann } & 0.96 & 26 \\ \text { Sellaphora utermoehlii (Hustedt) C.E.Wetzel \& D.G.Mann in Wetzel et al., } & 7.62 & 50 \\ \text { Sellaphora verecundiae Lange-Bertalot } & 0.17 & 8 \\ \text { Stauroneis anceps } \text { Ehrenberg } & 0.3 & 30 \\ \text { Staurosira tabellaria } \text { (W.Smith) Leuduger-Fortmorel } & 4.34 & 43 \\ \text { Staurosirella pinnata } \text { (Ehrenberg) D.M.Williams \& Round } & 11.82 & 55 \\ \text { Surirella amphioxys W.Smith } & 0.14 & 19 \\ \text { Tryblionella angustata } \text { W.Smith } & 0.1 & 13\end{array}$

\section{Biological remains}

\section{Diatoms}

Altogether about 140 taxa were distinguished during the study (Table 2); Amphora pediculus, Cocconeis neothumensis, Fragilaria brevistriata, and Karayevia clevei were not just abundant, but ever present members of the diatom assemblage. The small fragilaroid taxa (Staurosirella pinnata, Staurosira tabellaria) and small naviculoid forms like Navicula seminuloides and Sellaphora nigri, S. rotunda and S. utermoehlii were found abundant in some layers. The genus Amphora (A. pediculus and A. copulata) was also often present in the samples. Biofilm constituent diatoms growing on macrophytes are also often registered, e.g. Cocconeis neothumensis and $C$. neodiminuta. Three planktic taxa all belonging to centric diatoms, Aulacoseira granulata, Lindavia balatonis and Pantocsekiella ocellata significantly contribute to the assemblages. Two diatom species, Karayevia clevei and Belonastrum berolinensis are believed to be characteristic to Lake Balaton and were common in the majority of samples. The presence of the endemic diatom Pinnularia balatonis Pantocsek can also be detected along the entire core.

Diatom assemblage zones - succession of Siófok Basin

Relative frequency changes of the most common taxa throughout the sequence are shown in Figure 3 . In the diatom dataset, six statistically significant diatom assemblages zones (DAZ) were distinguished. DAZs are presented below according to depth:

SIO-DAZ-1 112-104 cm - Small, but robust fragilaroid taxa (mainly Staurosira pinnata) with the motile Caloneis schumanniana and Neidium iridis indicate an unstable and changing environment in the lower studied layer (Stenger-Kovács et al., 2018).

SIO-DAZ-2 104-82 cm - Fragilaria brevistriata, Aulacoseira granulata with small celled naviculoids (like Navicula seminuloides and Sellaphora utermoehlii) with the slightly motile 


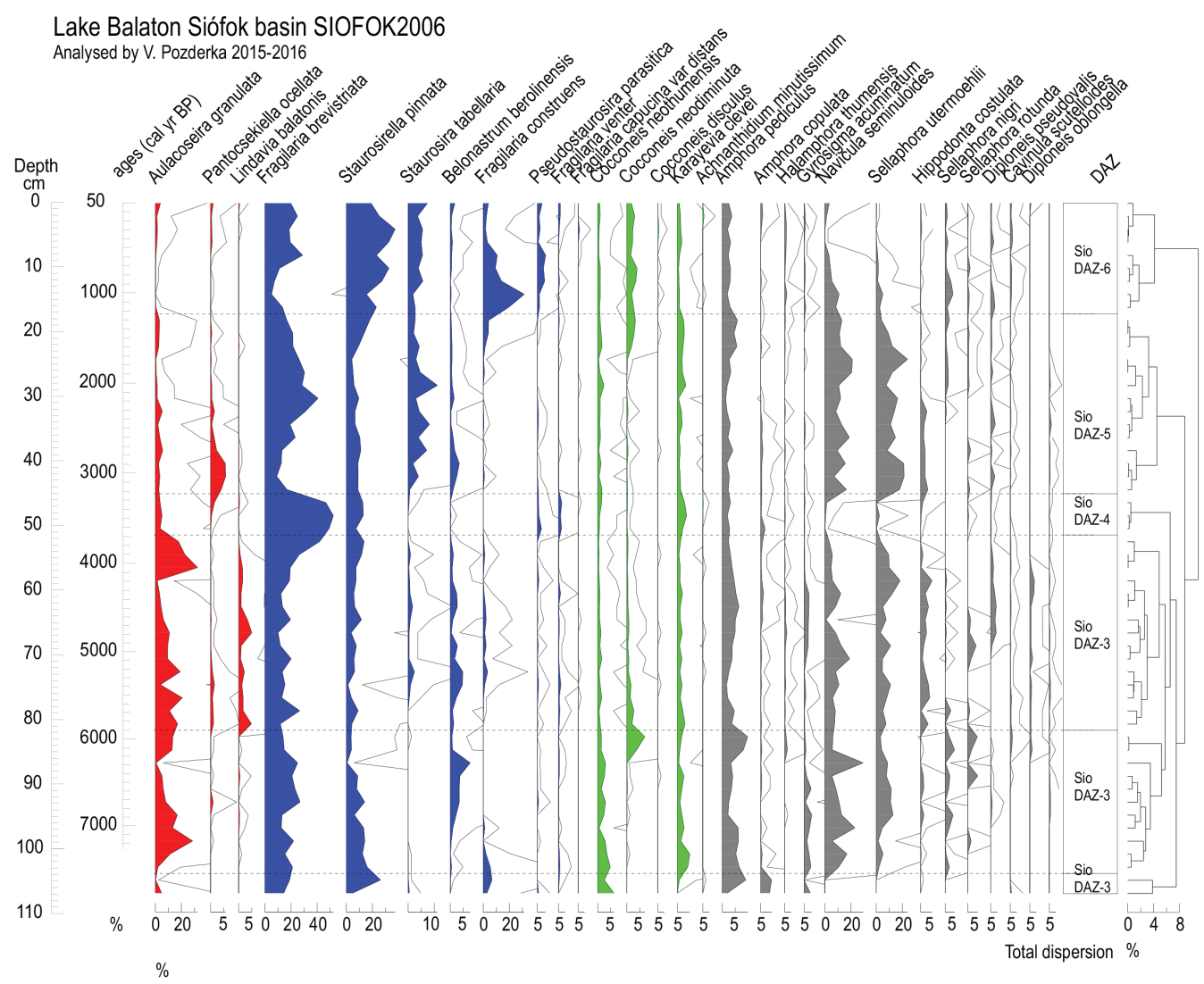

Figure 3. Relative abundance diagram of important diatom taxa in SIOFOK2006 core. Plankton taxa are marked by red; fragilaroid diatoms are blue, while the most typical periphytic taxa are green on the diagram. Lines without filling are exaggerated (10x) Sio-DAZ: diatom assemblage zone. Diagrama de abundancia relativa de importantes taxones de diatomeas en el testigo SIOFOK2006. Los taxones planctónicos están marcados con rojo; las diatomeas fragilaroid son azules, mientras que los taxones perifiticos más típicos son verdes en el diagrama. Las líneas sin relleno están exageradas (10x) Sio-DAZ: zona de agrupación de diatomeas.

Amphora pediculus are abundant in this zone. Cocconeis taxa are also present. The whole community points to rather diverse habitats in the basin referring to makrophytes. The species Belonastrum beroliensis is a not too common, but an often reported diatom in Lake Balaton, showing a minor maximum in this zone.

SIO-DAZ-3 $82-54 \mathrm{~cm}$ - The zone is characterized by similar assemblage as the one below, except for the species Lindavia balatonis becoming characteristic for this zone, indicating a rise in water level. The relatively high portion of Aulacoseira granulata confirms the reconstruction of high water level. The end of this zone shows a peak of $A$. granulata.

SIO-DAZ-4 54-46 cm - This very short zone is clearly dominated by the benthic, commonly chain-forming Fragilaria brevistriata.

SIO-DAZ-5 46-20 $\mathrm{cm}$ - Though the relative abundance of fragilaroid taxa is high, just as before and throughout the entire core, the small celled naviculoids like Navicula seminuloides, Sellaphora nigri, S. rotunda and $S$. uthermoehlii are also characteristic for the diatom assemblage. The ratio of planktic forms is very low. Staurosira tabellaria, one of the most characteristic taxon of Lake Balaton (Ács et al., 2009) has become abundant in this zone, confirming its continuing importance to this day.

SIO-DAZ-6 20-0 cm - The upper zone is clearly characterized by fragilaroids, of mainly the small celled type, but also the heavily silici- 
Lake Balaton Siófok basin

SIOFOK2006

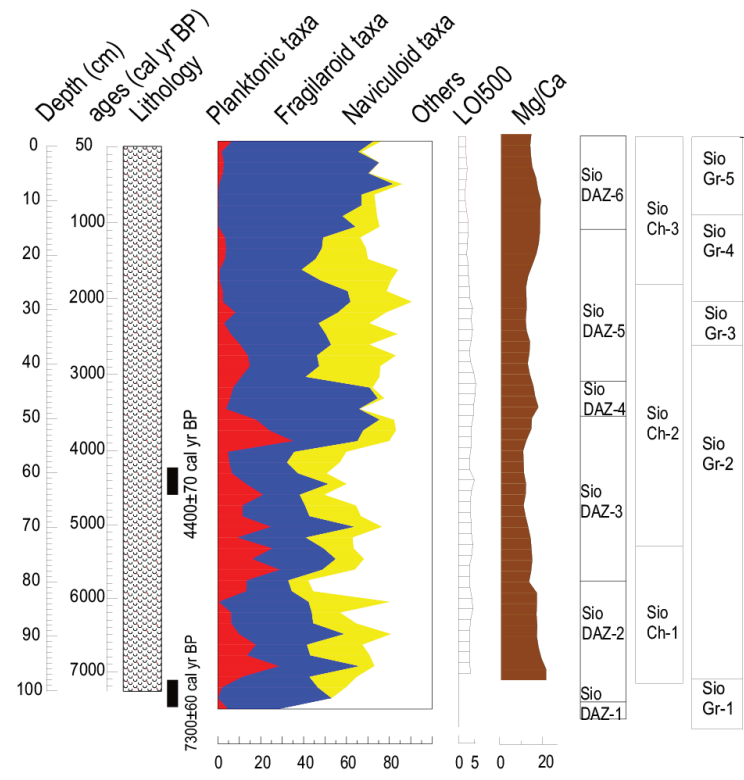

Figure 4. Lithology, $\mathrm{Ca} / \mathrm{Mg}$ ratio, organic material content (LOI 550 ), and zone boundaries of the studied proxies in SIOFOK2006 core. Note that the diatom, geochemical and grain size analysis were carried out not on the same length of core. Litologia, relación Ca/Mg, contenido de materia orgánica (LOI 550) y límites de zona de los proxies estudiados en el núcleo SIOFOK2006. Téngase en cuenta que el análisis de diatomeas, geoquímica y tamaño de grano no se llevó a cabo en la misma longitud del testigo.

fied Staurosirella pinnata is present. Increasing abundance of the epiphytic Cocconeis neodiminuta species is detected in this zone.

Lake level fluctuation is reconstructed based on diatom proxies reflecting the changed proportion of taxa characterized by different life forms in the assemblage. The assemblages dominated by planktic/tychoplanktic diatoms like Aulacoseira, Lindavia, Pantocsekiella and Belonastrum taxa indicate high lake levels (Fig. 4.). Fragilaroid taxa were found dominant throughout the core in the Siófok Basin due to the shallowness of Lake Balaton, but the increased ratio of planktic forms implied higher lake levels in the past. Lindavia balatonis was the dominant planktic species between $82-56 \mathrm{~cm}$. In these layers the species Aulacoseira granulata was also frequently observed, exhibiting a peak between $56-52 \mathrm{~cm}$.
At $46-38 \mathrm{~cm}$ the planktic Pantocsekiella ocellata reached higher abundance. According to this dataset Lake Balaton had a rather high, but fluctuating lake level before 2000 cal yr BP. Between $46-22 \mathrm{~cm}$ some small celled $(<10 \mu \mathrm{m})$ diatom taxa prevailed, suggesting a decreasing lake level. The species Navicula seminuloides, Sellaphora nigri, $S$. rotunda, and $S$. utermoehlii are also worthwhile to mention among the taxa that have been identified so far in the assemblages.

\section{DISCUSSION}

It is a well-known fact that the thickness of Holocene sediment shows a gradient along the long axis of the Lake Balaton, (e.g. Müller \& Wagner, 1978; Tullner \& Cserny, 2003; Visnovits, 2015): Holocene sediments can reach $10 \mathrm{~m}$ in the western part of the lake, where the river Zala with a rather extended catchment area enters, while it reaches only ca. $2 \mathrm{~m}$ in the central part of the eastern basin of the lake. Moreover, at some particular places along the lakeshore the Holocene sediments can be altogether missing (Visnovitz, 2015, Visnovitz et al., 2015). This highly variable sediment thickness of the lake can make paleolimnological interpretation difficult.

\section{Physical properties of SIOFOK2006 core}

The relationships between $\mathrm{LOI}$ at $550{ }^{\circ} \mathrm{C}\left(\mathrm{LOI}_{550}\right)$ and organic carbon content and between LOI at $950{ }^{\circ} \mathrm{C}\left(\mathrm{LOI}_{950}\right)$ and inorganic carbon content are currently accepted as a standard proxy for organic matters (Santisteban et al., 2004). Our results (very low $\mathrm{LOI}_{550}$ and high $\mathrm{LOI}_{950}$ ) are consistent with these main features, the ratio of biotas and calcareous mud of Lake Balaton.

The grain size distribution of the lake is more about diagenetic processes than the energy of water, as the sand fraction sized grains are autochthonous calcareous aggregates.

In the frame of EuLakes project four lakes were cored (two of them were shallow ones); and only Lake Balaton was found unsuitable for reconstruction of historical trophic state of the lake (https://www.eulakes-model.eu/outputs/ ecological-evolution/index.html). Undoubtedly, the shallowness and the strong influence of wind 
at Lake Balaton makes the sediment record of the lake far from an ideal subject for high-resolution paleo-ecological analyses, but our data and results obtained from SIOFOK2006 core show adequate preservation where the small, fine valves of diatoms were preserved in the mud (Kiss et al., 1999).

\section{Taxonomic remarks}

Although, Lake Balaton is one of the best studied lakes in the world, the diatom flora received less attention, except in the initial pioneering phase of scientific exploration in the 19th century (Lóczy 1916, Pantocsek 1901, 1913). Unfortunately, there is no recent overview, or checklist available of the diatom flora, only a few compilations were published at the middle of the last century (Szemes 1957, Tamás 1965).

The diatom flora of Lake Balaton is unique, with some endemic species like Pinnularia balatonis, a ubiquitous member of the diatom assemblage throughout the core. The taxonomy of fragilaroids, exhibiting huge variability with overlapping forms has been a challenge in Lake Balaton (Ács et al., 2009), especially when comparative analysis is required. It's worthwhile to mention the uncertainty of the species-level determination of Aulacoseira as A. aff. granulata in Lake Balaton. As previous paleolimnological studies of Lake Balaton revealed, the very rich diatom populations from the deeper sediment layers might help to resolve taxonomic problems. For example, the Aulacoseira taxa are dominant along the long axis of the lake as subfossils, a finding that helps to resolve the taxonomic difficulties concerning the genus in the lake. The species Belonastrum berolinensis, although a wide spread taxon (Round \& Maidana 2001), is generally rare in Hungary, but here in Lake Balaton, it is regarded as a typical, frequent element of the flora.

The above mentioned taxonomical uncertainties have been known for a long time, but this study on SIOFOK2006 core offers new taxonomic challenges concerning the small naviculoid species of Lake Balaton. Among the small naviculoid $(<10 \mu \mathrm{m})$, species like Navicula seminuloides, Sellaphora rotunda, S.nigrii and S. utermoehlii have been so far successfully identified from the assemblages. The accurate identification requiring the comparison with type materials is in progress, but still remains a challenge (as in Kiss et al., 2007).

\section{Diatom-based reconstruction on SIOFOK2006 core}

Changes in the planktic/benthic ratio of diatom assemblages indicate water level fluctuation (Heinsalu et al., 2007a, Korponai et al., 2010). In spite of the low organic material content $(\mathrm{LOI}<5$ $\%$ ), the samples prepared directly for siliceous microfossil analysis from the Holocene lacustrine sediments obtained in the Siófok Basin of Lake Balaton were suitable for diatom analysis.

Changes of water depth: Wind disturbed, very shallow water, without, or with only sporadic macrophytes can be reconstructed on the basis of the diatom assemblages from $7500 \mathrm{cal}$ yr BP. The higher lake level in the Holocene was reconstructed for the period 7500-2000 cal yr BP. Gradually decreasing water depth can be inferred from 2000 cal yr BP onward.

Several studies demonstrated uneven and mosaic hydrological changes from the entire area of the historical Lake Balaton (e.g. Cserny et al., (1991), Jakab et al., 2005, Rokob et al., 2008, Korponai et al., 2010). A multiproxy, non-diatom analysis was carried out in the north-western basin of the lake reconstructing the paleoenvironment (Jakab et al., 2005). This study suggested that from 5200 cal yr BP the water depth increased in the studied area. This is in line with our findings in the Siófok Basin at the south-east end of the lake. If the same phenomenon is observed in two opposite basins of the lake, then these data suggest that the lake level increase affected the entire lake and was in all probability climate-driven. In the last 2000 year history of the lake, the decreasing lake level can be due to human-induced pressure.

Mainly alkalophilous or indifferent diatom species were recorded along the sequence, indicating that there was no significant change in the water chemistry. Due to taxonomical uncertainties in Lake Balaton, and the lack of local training sets for paleoecological reconstruction, the calculation of quantitative phosphorous and $\mathrm{pH}$ for the 
studied sequence is considered premature, but it could be an urgent task for better understanding the current ongoing processes in the lake (Korponai et al., 2011). However, similar diatom records (the dominance of Aulacoseira taxa with small-sized fragilaroids) are often reported from large shallow lakes throughout the Holocene in Europe, maybe it is a typical assemblage for natural large lakes (Heinsalu et al., 2007a).

It is well-known that the Zala river in the south-west end of the lake is the major source of inflow. The nutrient load arriving with this river controls many environmental factors in a south-west/north-east gradient along the longitudinal axis of the lake (e.g. Müller \& Wagner, 1978; Tompa et al., 2014), and seemingly, the preservation potential of silica in the sediment essential for the diatom record, might change from location to location also. Another high resolution study carried out in the lake is the EuLakes project (WEB1 2018), with sampling sites in the Keszthely Basin, which is exactly at the opposite end of Lake Balaton compared to the present site. Two ca. $70 \mathrm{~cm}$ long cores were collected at a depth of ca. $3 \mathrm{~m}$. Even though the Keszthely Basin is a sub-basin of Lake Balaton receiving the highest nutrient load from the nearby Zala river during the past few decades, it is still characterised by high trophic level. However, their observation of "no diatom counts could be performed in the cleaned and mounted sub-samples due to the extremely scarce number of frustules and to their pronounced erosion. Only a few among the most robust and highly silicified taxa, could be identified in the observed samples. Planktic taxa are almost completely missing, with the exception of very rare specimens of Cyclotella ocellata Pantocsek (Pantocsekiella ocellata in this study) and C. radiosa (Grunow) Lemmermann / balatonis Pantocsek, (Lindavia radiosa and $L$. balatonis in this study) while the most represented benthic form is Fragilaria martyi (Hèribaud) Lange-Bertalot" is of limited value concerning the entire lake. The conclusion of the EuLakes project that "sediment diatoms of Lake Balaton are not representative of the living community, as a result of selective diatom elimination. The highly mineral and perturbed sediments of Lake Balaton likely represent a very aggres- sive environment for the most slender and delicate benthic and planktic taxa" can be easily refuted by the reasonably well preserved diatoms found in the Siófok Basin as presented here.

\section{CONCLUSIONS}

Several earlier studies demonstrated uneven and mosaic hydrological changes of the entire area of the historical Lake Balaton during the late glacial and Holocene times.

The use of diatoms in the paleoecological reconstruction of Lake Balaton has been questioned based on several less successful attempts conducted in the last decades. However, the SIOFOK2006 core yielded exploitable diatom flora for paleoenvironmental reconstruction.

Based on the diatom assemblages of the SIOFOK2006 core the following paleoenvironment can be reconstructed for the Siófok Basin of Lake Balaton, a wind disturbed, very shallow water without, or with only sporadic macrophytes living at the bottom of the lake. This environment prevailed from the basal layers of the core (from ca. 7500 cal yr BP) to the present, while gradually decreasing water depth can be inferred from 2000 cal yr BP onward.

Finding a high ratio of small celled naviculoid forms in the upper part of this sequence is unique, as no other earlier studied cores contained these forms in such high abundance.

\section{ACKNOWLEDGEMENTS}

The research was supported by the National Research, Development and Innovation Office NKFIH (OTKA 119208, CRYPTIC project) and partly by the GINOP-2.3.2-15-2016-00019 grant. Special thanks to B. Becht and P. Sheridan (Moore Park College LA) for language corrections. We are very grateful for the anonymous reviewers for their advices.

\section{REFERENCES}

ÁCS, É., E. A. MORALES, K. T. KISS, B. BOLLA, A. PLENKOVIĆ-MORAJ, M. N. RESKÓNÉ \& L. ECTOR. 2009. Staurosira grigorszkyi nom. nov. (Bacillariophyceae) an 
araphid diatom from Lake Balaton, Hungary, with notes on Fragilaria hungarica Pantocsek. Nova Hedwigia, 89: 469-483. DOI: 10.1127/0029-5035/2009/0089-0469

ÁCS, É., E. ARI, M. DULEBA, M. DRESSLER, S.I. GENKAL, E. JAKÓ, F. RIMET, L. ECTOR \& K.T. KISS. 2016. Pantocsekiella, a new centric diatom genus based on morphological and genetic studies. Fottea, 16: 56-78. DOI: $10.5507 /$ fot.2015.028

BATTARBEE, R. W. 1986. Diatom analysis. In: Handbook of Holocene palaeoecology and palaeohydrology, B. E. Berglund, (ed.): 527-570. Chichester: Wiley.

BENNET, K. D. 2005. Documentation for psimpoll 4.25 and psimcomb 1.3. C program for plotting pollen diagram and analysis pollen data. http://www.chrono.qub.ac.uk/psimpoll/ download/doc/psimpoll.ps

BUCZKÓ, K., L. VÖRÖS \& T. CSERNY. 2005. The diatom flora and vegetation of Lake Balaton from sediment cores according to Márta Hajós `s legacy. Acta Botanica Hungarica, 47: 75-115. DOI: 10.1556/abot.47.2005.1-2.10

BUCZKÓ, K., E. K. MAGYARI, C. STENGER-KOVÁCS \& J. KORPONAI. 2009. The Holocene diatom flora of Zalavári pond (Lake Balaton system, Hungary). Algological Studies, 132: 35-73. DOI: 10.1127/1864-1318/ 2009/0132-0035

CSERNY, T. 2002. Results of an investigation into Quaternary lacustrine sediments in Lake Balaton (in Hungarian with English abstract). Földtani Közlöny, 132: 193-213.

CSERNY, T., E. NAGY-BODOR \& M. HAJÓS. 1991. Contributions to the sedimentology and evolution history of Lake Balaton. In: Quaternary environment in Hungary, Studies in Geography in Hungary, 26. Pécsi, M. \& F. Schweitzer. (eds): 75-84. Akadémiai Kiadó, Budapest.

CSERNY, T. \& E. NAGY-BODOR. 2000. Limnogeology of Lake Balaton (Hungary). In: Lake basins through space and time: $A A P G$ studies in geology, Gierlowski-Kordesch, E. H. \& K. R. Kelts. (eds) 46: 605-618. American Association of Petroleum Geologists (AAPG), Tulsa. http://archives.datapages.com/data/ specpubs/study46/ch58/chapter58.htm
ENTZ, G. \& O. SEBESTYÉN. 1946. Das Leben des Balaton-Sees. Arbeiten des Ungarischen Biologischen Forschungsinstitutes, 16: 179-411.

GUIRY, M. D. \& G. M. GUIRY. 2016. AlgaeBa$s e$. World-wide electronic publication, National University of Ireland, Galway. http://www.algaebase.org; searched during February 2016.

HATVANI, I. G., J. KOVÁCS, I. S. KOVÁCS, P. JAKUSCH \& J. KORPONAI. 2011. Analysis of long-term water quality changes in the Kis-Balaton Water Protection System with time series-, cluster analysis and Wilks' lambda distribution. Ecological Engineering, 37: 629-635. DOI: 10.1016/j.ecoleng.2010. 12.028

HEINSALU, A., T. ALLIKSAAR, A. LEEBEN \& T. NÕGES. 2007a. Sediment diatom assemblages and composition of pore-water dissolved organic matter reflect recent eutrophication history of Lake Peipsi (Estonia/Russia). In: Shallow Lakes in a Changing World: 133-143. Springer, Dordrecht. DOI: 10.1007/ s10750-007-8615-2

HEINSALU, A., H. LUUP, T. ALLIKSAAR, P. NÕGES \& T. NÕGES. 2007b. Water level changes in a large shallow lake as reflected by the plankton: periphyton-ratio of sedimentary diatoms. In: European Large Lakes Ecosystem changes and their ecological and socioeconomic impacts: 23-30. Springer, Dordrecht. DOI: $10.1007 / \mathrm{s} 10750-007-9206-\mathrm{y}$

HEIRI, O., A. F. LOTTER \& G. LEMCKE. 2001. Loss on ignition as a method for estimating organic and carbonate content in sediments: reproducibility and comparability of results. Journal of Paleolimnology, 25: 101-110. DOI: 10.1023/A:1008119611481

HOFMANN, G., M. WERUM \& H. LANGE-BERTALOT. 2011. Diatomeen im Süßwasser-Benthos von Mitteleuropa: Bestimmungsflora Kieselalgen für die ökologische Praxis; über 700 der häufigsten Arten und ihrer Ökologie. Gantner.

ISTVÁNOVICS, V., A. CLEMENT, L. SOMLYÓDY, A. SPECZIÁR, L. G.-TÓTH \& J. PADISÁK. 2007. Updating water quality targets for shallow Lake Balaton (Hungary), 
recovering from eutrophication. Hydrobiologia, 581: 305-318. DOI: 10.1007/s10750-0060509-1

ISTVÁNOVICS, V. \& M. HONTI. 2018. Coupled simulation of high-frequency dynamics of dissolved oxygen and chlorophyll widens the scope of lake metabolism studies. Limnology and Oceanography, 63: 72-90. DOI: 10.1002/lno.10615

JAKAB, G., P. SÜMEGI \& ZS. SZÁNTÓ. 2005. Késő-glaciális és holocén vízszintingadozások a Szigligeti-öbölben (Balaton) makrofosszília vizsgálatok eredményei alapján. (Late Glacial and Holocene water level changes in the Szigliget Bay, Lake Balaton based on macrofossil investigations.). Földtani Közlöny, 135: 404-432.

JUGGINS, S. 2012. Rioja: Analysis of Quaternary Science Data, R Package.

KEARNS, C., N. HAIRSTON \& D. KESLER. 1996. Particle transport by benthic invertebrates: its role in egg bank dynamics. Hydrobiologia, 332: 63-70. DOI: 10.1007/BF00020780

KISS, K. T., R. KLEE \& E. HEGEWALD. 1999. Reinvestigation of the original material of Cyclotella ocellata Pantocsek (Bacillariophyceae). Algological Studies, 93: 39-53.

KISS, K. T., É. ÁCS, K. É. SZABÓ, M. R. MIRACLE \& E. VICENTE. 2007. Morphological observations on Cyclotella distinguenda Hustedt and $C$. delicatula Hustedt from the core sample of a meromictic karstic lake of Spain (Lake La Cruz) with aspects of their ecology. Diatom Research, 22: 287-308. DOI: 10.1080/0269249X.2007.9705716

KORPONAI, J., M. BRAUN, K. BUCZKÓ, I. GYULAI, L. FORRÓ, J. NÉDLI \& I. PAPP. 2010. Transition from shallow lake to wetland: A multi-proxy case study in Zalavári Pond, Balaton, Hungary. Hydrobiologia, 641: 225-244. DOI: 10.1007/s10750-009-0087-0

KORPONAI, J., K. A. VARGA, T. LENGRÉ, I. PAPP, A. TÓTH \& M. BRAUN. 2011. Paleolimnological reconstruction of the trophic state in Lake Balaton (Hungary) using Cladocera remains. Hydrobiologia, 676: 237-248. DOI: $10.1007 / \mathrm{s} 10750-011-0898-7$

LÓCZY, L. 1916. Die geologischen Formationen der Balatongegend und ihre regionale Tekto- nik (Erste Sektion). Physische Geographie des Balatonsees und seiner Umgebung (Erster Band). Die Geomorphologie des Balatonsees und seiner Umgebung (Erster Teil). Resultate der Wissenschaftlichen Erforschung des Balatonsees. Balaton-ausshusse der ung. Geographischen Gesellschaft. Wien.

MÜLLER, G. \& F. WAGNER. 1978. Holocene carbonate evolution in Lake Balaton (Hungary): a response to climate and impact of man. In: Modern and Ancient Lake Sediments (Special Publication 2 of the International Association of the Sedimentologists : Matter A. \& M. E. Tucker. (eds): 57-81. Blackwell Sci. Publ. DOI: 10.1002/9781444303698.ch4 PANTOCSEK, J. 1901. Die Kieselalgen oder Bacillarien des Balaton. - In: Resultate der wissenschaftlichen Erforschung des Balatonsees. II. Band. Budapest Druck der K. und K. Hofbuchdruckerei des Victor Hornyánszky. 112 pp. Pls 1-17. DOI: 10.5962/bhl.title.64368 PANTOCSEK, J. 1913. A Balaton fenékalatti mederfúrások sorozatai mélységi próbáiban talált Bacilláriák táblázatos kimutatása/Tabular presentation of the diatoms found in the samples of the serial deep borings under the bottom of the Lake Balaton. A Balaton Tudományos Tanulmányozásának Eredményei.Vol.1. Part 2. Section 1, Supplement, 4: 563. Magyar Földrajzi Társaság Balaton Bizottsága, Budapest.

ROKOB, K., K. BUCZKÓ \& L. VÖRÖS. 2008. A Balaton vízszint-változásainak és vízminőségének rekonstrukciója kovamoszatok alapján a Siófoki-medencében. (Diatom based reconstruction of water level changes and water quality in Siófok-basin of Lake Balaton). Hidrológiai Közlöny, 88: 175-178.

ROMERO-VIANA, L., M. R. MIRACLE, C. LÓPEZ-BLANCO, E. CUNA, G. VILACLARA, J. GARCIA-ORELLANA, B. J. KEELY, A. CAMACHO \& E. VICENTE. 2009. Sedimentary multiproxy response to hydroclimatic variability in Lagunillo del Tejo (Spain). Hydrobiologia, 631: 231-245. DOI: 10.1007/ s10750-009-9813-x

ROUND, F. E. \& N. I. MAIDANA. 2001. Two problematic freshwater araphid taxa re-classified in new genera. Diatom, 17: 21-28. DOI: 
10.11464/diatom 1985.17.0 21

SANTISTEBAN J. I., R. MEDIAVILLA, E. LOPEZ-PAMO, C. J. DABRIO, M.B. ZAPATA, M. J. GARCÍA, S., CASTANO \& P. E. MARTÍNEZ-ALFARO. 2004. Loss on ignition: a qualitative or quantitative method for organic matter and carbonate mineral content in sediments?. Journal of Paleolimnology, 32: 287-99. DOI: 10.1023/B:JOPL. 0000042999.30131.5b

STENGER-KOVÁCS, C., K. KÖRMENDI, E. LENGYEL, É. HAJNAL, A. ABONYI, B. SZABÓ, K. BUCZKÓ \& J. PADISÁK. 2018. Expanding the trait-based concept of benthic diatoms: development of trait- and species-based indices for conductivity as the master variable of ecological status in continental saline lakes. Ecological Indicators, 95: 63-74. DOI: 10.1016/j.ecolind.2018.07.026

STOERMER, E \& J. P. SMOL. 1999. The Diatoms: Applications for the Environmental and Earth Sciences. Cambridge University Press. DOI: 10.1017/cbo9780511613005

STUIVER, M., P. J. REIMER \& R. W. REIMER. 2005. CALIB 5.0 http://www.calib.qub.ac.uk/ crev50

SZEMES, G. 1957. Die Diatomeen des Balatonsees. (A Balaton kovamoszatai.). Annales Instítuti Biologici (Tihany) Hungaricae Academiae Scientiarum, 24: 193-270.

TAMÁS, G. 1965. Kieselalgen des Balaton-Sees 1956-1961. Annales Instituti Biologíci (Tihany) Hungaricae Academiae Scientiarum, 30: 167-218.

TOMPA, E., I. NYIRÖ-KÓSA, A. ROSTÁSI, T.
CSERNY \& M. PÓSFAI. 2014. Distribution and composition of $\mathrm{Mg}$-calcite and dolomite in the water and sediments of lake Balaton. Central European Geology. 57: 113-136. DOI: 10.1556/CEuGeol.57.2014.2.1

TULLNER, T. \& T. CSERNY. 2003. New aspects of lake-level changes: Lake Balaton, Hungary. Acta Geologica Hungarica, 46: 215-238. DOI: 10.1556/AGeol.46.2003.2.8

VISNOVITZ, F. 2015. Balatoni vízi szeizmikus szelvények környezetgeofizikai vizsgálata Environmental geophysical study of water seismic profiles at Lake Balaton. Ph.D. Thesis Eötvös Lóránd University Budapest.

VISNOVITZ, F., F. HORVÁTH, N. FEKETE \& V. SPIESS. 2015. Strike-slip tectonics in the Pannonian Basin based on seismic surveys at Lake Balaton. International Journal of Earth Sciences, 104: 2273-2285. DOI: 10.1007/ s00531-015-1179-x

WEB1 https://www.eulakes-model.eu/outputs/ ecological-evolution/index.html accessed on 27.07.2018.

WETZEL, C. E., L. ECTOR, B. VAN DE VIJVER, P. COMPERE \& D. G. MANN 2015. Morphology, typification and critical analysis of some ecologically important small naviculoid species (Bacillariophyta). Fottea, 15: 203-234. DOI: 10.5507/fot.2015.020

WILLIAMSON, C. E., J. E. SAROS, W. F. VINCENT \& J. P. SMOL. 2009. Lakes and reservoirs as sentinels, integrators, and regulators of climate change. Limnology and Oceanography, 54: 2273-2282. DOI: 10.4319/10.2009.54. $6 \_$part_2.2273

Con el apoyo de:

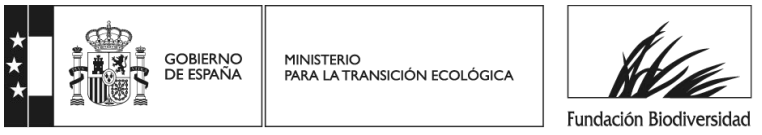

